\title{
Robot-assisted simple prostatectomy: the evolution of a surgical technique
}

\author{
Gilberto J. Rodrigues ${ }^{1}$, Guilherme V. Sawczyn ${ }^{1}$, Giuliano B. Guglielmetti ${ }^{1}$, Arnaldo J. C. Fazoli ${ }^{1}$, \\ Luís H. R. Tanure ${ }^{2,3,4}$, William C. Nahas ${ }^{1}$, Rafael F. Coelho ${ }^{1}$ \\ ${ }^{1}$ Instituto do Câncer do Estado de São Paulo, São Paulo, SP, Brasil; ${ }^{2}$ Américas Centro Integrado de \\ Oncologia, São Paulo, SP, Brasil; ${ }^{3}$ Hospital Paulistano, São Paulo, SP, Brasil; ${ }^{4}$ Hospital 9 de Julho, \\ São Paulo, SP, Brasil
}

\section{ABSTRACT}

Purpose: Enucleation of a large prostate is the best surgical choice for patients refractory to clinical treatment $(1,2)$. Since the first robot-assisted simple prostatectomy (RASP) was described (3, 4), some technical modifications (5-7) and different approaches to reach the adenoma have been proposed $(8,9)$. The aim of this video is to demonstrate three different techniques of RASP.

Materials and Methods: The first procedure begins with a transversal incision over the bladder neck, the second is a transvesical approach and the last one is a Retzius-sparing RASP. All techniques were performed with a vesico-urethral anastomosis.

Results: Three patients underwent RASP, each one with a different approach. Patients presented mean age of $66 \pm 4.4$ years, PSA baseline level of $7.8 \pm 3 \mathrm{ng} / \mathrm{mL}$, IPSS score of $17.7 \pm 4.5$, maximum urine flow of $8.3 \pm 1.5 \mathrm{~mL} / \mathrm{seg}$ and $122.3 \pm 11.2 \mathrm{~cm} 3 \mathrm{of}$ prostate volume. The mean operative time was $63 \pm 8$ minutes, estimated blood loss of $106.7 \pm 11.5 \mathrm{~mL}$, prostate weight of the surgical specimen of $106.3 \pm 8$ grams and 1 day of length of stay. No continuous bladder irrigation was required and there was no complication. The mean postoperative PSA and IPSS were $0.7 \pm 0.3 \mathrm{ng} / \mathrm{mL}, 4.7 \pm 1.5$. The maximum urine flow raised to $20 \pm 4.4 \mathrm{~mL} / \mathrm{seg}$.

Conclusions: RASP with vesico-urethral anastomosis allowed minimal blood loss, short length of stay and great functional outcomes. All the three approaches allowed to perform this technique in a safe way, while showing different alternatives to reach the adenoma.

\section{CONFLICT OF INTEREST}

None declared. 


\section{REFERENCES}

1. Gravas S, Cornu JN, Gacci M, Gratzke C, Herrmann TRW, Mamoulakis C, et al. Management of Non-Neurogenic Male Lower Urinary Tract Symptoms (LUTS), incl. Benign Prostatic Obstruction (BPO). EAU Guidelines 2020. [Internet]. Available at. <https://uroweb.org/guideline/ treatment-of-non-neurogenic-male-luts/>

2. Cimen, H. I., Atik, Y. T., Gul, D., Uysal, B., \& Balbay, M. D. (2019). Serving as a bedside surgeon before performing robotic radical prostatectomy improves surgical outcomes. International braz j urol : official journal of the Brazilian Society of Urology, 45, 1122-8.

3. Sotelo R, Clavijo R, Carmona 0, Garcia A, Banda E, Miranda M, Fagin R. Robotic simple prostatectomy. J Urol. 2008;179:513-5.

4. Qi F, Wang S, Xu H, Gao Y, Cheng G, Hua L. A comparison of perioperative outcome between robot-assisted and laparoscopic radical prostatectomy: experience of a single institution. Int Braz J Urol. 2019; 45:695-702.
5. Coelho RF, Chauhan S, Sivaraman A, Palmer KJ, Orvieto MA, Rocco B, et al. Modified technique of robotic-assisted simple prostatectomy: advantages of a vesico-urethral anastomosis. BJU Int. 2012; 109:426-33.

6. Neumaier MF, Segall CH Júnior, Hisano M, Rocha FET, Arap S, Arap MA. Factors affecting urinary continence and sexual potency recovery after robotic-assisted radical prostatectomy. Int Braz J Urol. 2019; 45:703-12.

7. Evren I, Hacislamoglu A, Eksi M, Yavuzsan AH, Baytekin $F$, Çolakoglu $Y$, et al. The impact of single positive surgical margin features on biochemical recurrence after robotic radical prostatectomy. Int Braz J Urol. 2019; 45:45-53.

8. Cockrell R, Bonzo J, Lee D. Robot-Assisted Simple Prostatectomy. J Endourol. 2018; 32(S1):S33-S38.

9. De Concilio B, Silvestri T, Justich M, Vedovo F, Zeccolini G, Celia A. A Novel Technique for Robotic Simple Prostatectomy: An Evolution of Retzius-sparing Technique. Urology. 2018; 115:185.

\section{Correspondence address:}

Gilberto J. Rodrigues, MD

Submitted for publication:

August 17, 2020

Instituto do Câncer do Estado de São Paulo

Accepted after revision:

Av. Dr. Arnaldo, 251, Cerqueira César

São Paulo, SP, 01246-000, Brasil

August 26, 2020

E-mail: rodrigues@outlook.com

Published as Ahead of Print:

December 20, 2020

\section{ARTICLE INFO}

Gilberto José Rodrigues

https://orcid.org/0000-0001-6839-8439

Available at: http://www.intbrazjurol.com.br/video-section/20200744_Rodrigues_et_al

Int Braz J Urol. 2021; 47 (Video \#12): 682-3 